\title{
Sciences
}

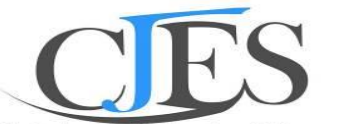

Cypriot Journal of Educational Sciences

\section{The role of the possibilities of the influence of traditional and modern art on the self-presentation of future teachers.}

Smanova Akmara ${ }^{*}$, Abai Kazakh National Pedagogical University, Institute of Arts, Culture and Sports, Department of Design, Dostyk Avenue 13, Almaty, Kazakhstan. https://orcid.org/0000-0003-3547-4743

Nebessayeva Zhanar Orynbekovna ${ }^{b}$, Doctor of Philosophy PhD, Executive Associate Professor, Dean of the Department Information technology and natural sciences, Syrdaria University, Zhetysay city, Republic of Kazakhstan, https://orcid.org/0000-0003-4358-3923

Bekbolatova Kuralay c, Abai Kazakh National Pedagogical University, Institute of Arts, Culture and Sports, Department of Design, Dostyk Avenue 13, Almaty, Kazakhstan

Alzhanov Gadilbek ${ }^{d}$, Abai Kazakh National Pedagogical University. https://orcid.org/0000-0001-9552-5181.

Jartybayeva Zhamila Dzhaybulovnae, Assistant Professor, magister of "Fine Arts and Design" department, M.Auezov South Kazakhstan university, https://orcid.org/0000-0002-2058-2939

Rsmakhanbetova Shakhrizada Erkinkyzyf, Assistant Professor, magister of "Fine Arts and Design" department, M.Auezov South Kazakhstan university, https://orcid.org/0000-0001-5896-6842

Kunzhigitova Gulnur Bektemirovnas, Assistant Professor of "Fine Arts and Design" department, M.Auezov South Kazakhstan university, https://orcid.org/0000-0002-4827-9843

\section{Suggested Citation:}

Akmara, S., Orynbekovna, N.Z., Kuralay, B., Dzhaybulovna, J. Z., Erkinkyzy, R. S. \& Bektemirovna, K. (.2021). The Role of the Possibilities of the Influence of Traditional and Modern Art on the Self-presentation of Future Teachers. Cypriot Journal of Educational Science. 16(5), 2713-2725. https://doi.org/10.18844/cjes.v16i5.6361

Received from July 11, 2021; revised from August 19, 2021; accepted from October 07, 2021.

(C)2021 Birlesik Dunya Yenilik Arastirma ve Yayincilik Merkezi. All rights reserved.

\begin{abstract}
Current research has considered the possibilities of the influence of traditional and contemporary art on self-presentation among future teachers at the stage of university professional training in the framework of the educational process and students' activities. The purpose of the article is to determine the effectiveness of the implementation of the complex influence of traditional and contemporary art in pedagogical conditions, as a way of organizing and managing the process of forming a culture of self-presentation among future teachers. The research collected data through a questionnaire and the sample consisted of 216 students. The collected data was analysed using statistical methods such as student t-tests and percentages. The main results are that the developed and implemented author's complex of possibilities for the influence of traditional and contemporary art in pedagogical conditions ensures its successful formation in future teachers at the stage of professional training at the university.
\end{abstract}

Keywords: contemporary art; professional training; self-presentation; traditional art.

* ADDRESS FOR CORRESPONDENCE Smanova Akmara, Abai Kazakh National Pedagogical University, Institute of Arts, Culture and Sports, Department of Design, Dostyk Avenue 13, Almaty, Kazakhstan.

E-mail address: gold 15k1@mail.ru 
Akmara, S., Orynbekovna, N.Z., Kuralay, B., Dzhaybulovna, J. Z., Erkinkyzy, R. S. \& Bektemirovna, K. (.2021). The Role of the Possibilities of the Influence of Traditional and Modern Art on the Self-presentation of Future Teachers. Cypriot Journal of Educational Science. 16(5), 27132725. https://doi.org/10.18844/cjes.v16i5.6361

\section{Introduction}

In the modern period, in the training programs for future teachers, not enough attention is paid to the formation of a culture of influence of the traditional and modern art of self-presentation as one of the most important aspects of the professional and pedagogical culture of a teacher. One of the ways to solve this problem is the optimization of pedagogical work (Ödalen et al., 2019) through educational and extracurricular activities with future teachers (Tsybulsky \& MuchnikRozanov, 2019) at the stage of professional training at the university (Spiridonova, 2015).

Self-presentation of the influence of traditional and contemporary art in the professional activity of a teacher in modern psychological and pedagogical research is considered in various aspects. Thus, a number of scientific works are devoted to the study of self-presentation and the related phenomenon of "the image of a cultural teacher". Gluhih (2012) considers the image of a modern teacher as a condition for the formation of his professional competence, Chekalina (2012), examines the features of the influence of traditional and modern art of self-presentation of women teachers, Semenova (2009) studies the features of self-presentation of male teachers , Anokhina(2013) studies self-presentation of a teacher in the Internet space. Others pays attention to the teacher's image as a component of the quality of the system of geometric-graphic training of students, and the teacher's image as a component of his professional personality.

Most researchers also pay attention to the pedagogical image of a modern teacher of higher education, Kalyuzhny (2004) investigates the psychology of the formation of the teacher's image. The scientific work "Pedagogical education with updated content based on an integrative approach" describes well the role of the influence of art on the activities of a modern teacher in modern education Nebessayeva et al. (2021).

Other researchers explore the psychological conditions for the formation of the image of a teacher of higher education and highlights the psychological and pedagogical foundations of the formation of the image competence of a teacher of a university. Frenzel, Taxer, Schwab and Kuhbandner (2019) in their experimental study show the joint influence of enthusiasm and teacher motivation on the motivation and experience of students. Researchers come to similar conclusions (Schmidt et al., 2017; Chen, 2019; Hayik, 2019).

Similarly, other researchers consider the image of a modern university teacher through the eyes of a student, and foreign researchers Forster-Heinzer et al., (2019)- on the basis of students' impressions in the classroom. These researchers explore self-presentation and effective communication as the basic competencies of a teacher, consider self-presentation as the most important element of the teacher's professional culture and also consider the features of self-presentation of teachers in a situation of pedagogical interaction "student teacher".

Saidah, Louvet and Pansu substantiate the influence of self-presentation on the perception of a person as successful in the process of learning interaction (2019). Bulavkina and Mayer consider the creative self-presentation of a preschool teacher in the context of a professional skill competition (2018).

In our opinion, self-presentation with the influence of traditional and contemporary art of a teacher is not sufficiently considered by modern pedagogy in the aspect of professional culture, the possibilities of its formation during the period of professional training at a university are not sufficiently disclosed. 
Akmara, S., Orynbekovna, N.Z., Kuralay, B., Dzhaybulovna, J. Z., Erkinkyzy, R. S. \& Bektemirovna, K. (.2021). The Role of the Possibilities of the Influence of Traditional and Modern Art on the Self-presentation of Future Teachers. Cypriot Journal of Educational Science. 16(5), 27132725. https://doi.org/10.18844/cjes.v16i5.6361

\subsection{Purpose of research}

The authors investigate the problem of the possibilities of the influence of traditional and contemporary art on self-presentation among future teachers at the stage of university professional training in the framework of the educational process and students' activities. The purpose of the article is to determine the effectiveness of the implementation of the complex influence of traditional and contemporary art in pedagogical conditions, as a way of organizing and managing the process of forming a culture of self-presentation among future teachers based on the author's theoretical ideas about the essence of this phenomenon.

\section{Research methods and Materials}

\subsection{Data collection method}

The study was conducted from 2020 to 2021.The study was carried out in the logic of a formative psychological and pedagogical experiment, the material obtained from the collection of empirical data was analyzed and generalized.

By a complex of pedagogical conditions, we mean a set of forms, methods and techniques for organizing pedagogical activities aimed at forming the components of the culture of influence of traditional and contemporary art of self-presentation (the formation of knowledge and skills about the influence of traditional and modern art of self-presentation, about oneself as a subject of selfpresentation and about other people; mastering the methods and means of influence of traditional and contemporary art of self-presentation, which determine its effectiveness; assignment of the significance and value of the influence of traditional and contemporary art of self-presentation in the life and work of a teacher and oneself as a subject of self-presentation, self-knowledge as the basis of self-regulation and self-development of a personality in the process of influence of traditional and contemporary art self-presentation, manifestation of creativity in the process of influence of traditional and modern art of self-presentation) and carried out through educational and extracurricular activities of students.

The collection of empirical data was carried out using the following methods: criterionoriented test "Literacy in self-presentation" (Kolmogorova \& Spiridonova,2015;2017); SelfMonitoring Scale (Snyder, 1979); "Scale of measuring tactics of self-presentation", "Scale of perfectionist self-presentation"; Terminal Values Questionnaire; "Methodology for determining the level of formation of pedagogical reflection"; "Methodology for the study of self-attitude".

\subsection{Participants}

The sample consisted of 216 students enrolled in different profiles of the pedagogical direction of training: "Professional training", "Fine arts and artistic work", "Design", "Primary education", aged 17 to 23 years.

\subsection{Data analysis}

The data obtained were interpreted and subjected to statistical analysis using percentage and qualitative analyses using Student's t-test. The analysis carried out makes it possible to systematize ideas about the phenomenon of the culture of influence of the traditional and modern art of the teacher's self-presentation as an integral part of the teacher's professional culture. Based on the presented definition and components of the teacher's self-presentation culture, a complex of pedagogical conditions of the influence of traditional and modern art was developed, contributing to 
Akmara, S., Orynbekovna, N.Z., Kuralay, B., Dzhaybulovna, J. Z., Erkinkyzy, R. S. \& Bektemirovna, K. (.2021). The Role of the Possibilities of the Influence of Traditional and Modern Art on the Self-presentation of Future Teachers. Cypriot Journal of Educational Science. 16(5), 27132725. https://doi.org/10.18844/cjes.v16i5.6361

the formation of a culture of self-presentation among future teachers at the stage of university professional training.

\subsection{Data collection process}

The study of the formation of a culture of influence of traditional and modern art of selfpresentation in the psychological and pedagogical conditions of future teachers was carried out from the standpoint of an activity approach. The following stages: ascertaining, forming and controlling. The culture of influence of traditional and contemporary art of self-presentation was considered from the standpoint of Russian cultural-historical psychology and cultural studies.

In our work, we consider the essential characteristics and structure of the culture of influence of traditional and modern art of self-presentation in the context of the psychological culture of the teacher. In the study, we adhere to the position of Kolmogorova, (2013) which defines the general culture of the individual as follows: it is an integral part of the basic culture as a systemic characteristic of a person, allowing him to effectively self-determine in society and self-actualize in life, contributing to self-development and successful social adaptation, satisfaction with his own life. It includes literacy and competence in the psychological aspect of understanding the human essence, the inner world of a person (including himself), human relations and behavior, a humanistically oriented value-semantic sphere (aspirations, interests, worldview, value orientations), developed reflection, as well as art in aspect of human knowledge and their own life (Kolyuzhny, 2004; Kolmogorova, 2013).

In turn, according to the general characteristics of the structure of the psychological culture of the personality, identified by Kolmogorova, (2013) in the structure of the culture of self-presentation of the teacher, we distinguish the cognitive, competence, value-semantic, reflexive-evaluative and creative components (Kolmogorova \& Spiridonova, 2017).

In our study, we relied on the phenomenological basis for identifying types of culture, presented in the work of Kolmogorova (2013). On this basis, the culture of self-presentation is considered among such types of personality culture as the culture of thinking, the culture of emotions and feelings, the culture of influence of traditional and modern art of personal safety, moral culture, the culture of life self-determination, etc. That is, from the point of view of familiarization with the achievements of the sciences), it is possible to distinguish such types of personality culture as mathematical, historical, ecological, psychological, etc.

In our study, we consider the culture of self-presentation as an integral part of the psychological culture of a person, which includes a set of knowledge and skills necessary for selfpresentation, and their effective application in the process of self-presentation, value attitude to the content and awareness of the importance of self-presentation, reflection of the process and result of self-presentation, creativity in self-presentation.

This basic definition was taken by us as a basis when determining the culture of influence of traditional and contemporary art of teacher's self-presentation, taking into account the content and specifics of his professional activity and professional training. This definition corresponds to the previously identified components in the teacher's self-presentation as an integral part of his psychological culture (Popova, 2004; Kolmogorova \& Spiridonova, 2015; Spiridonova, 2015). By the culture of influence of traditional and modern art of teacher's self-presentation, we mean an integral part of the teacher's professional culture, which includes a set of knowledge and skills about self- 
Akmara, S., Orynbekovna, N.Z., Kuralay, B., Dzhaybulovna, J. Z., Erkinkyzy, R. S. \& Bektemirovna, K. (.2021). The Role of the Possibilities of the Influence of Traditional and Modern Art on the Self-presentation of Future Teachers. Cypriot Journal of Educational Science. 16(5), 27132725. https://doi.org/10.18844/cjes.v16i5.6361

presentation and their application to increase its effectiveness in professional activity and communication, value-semantic attitude to self-presentation and awareness of its significance, reflection of the process and result of self-presentation in pedagogical activity and the manifestation of creativity in the presentation of oneself as a teacher in front of students in the process of professional activity and professional communication.

\section{Research results}

At the ascertaining stage of the experiment, the initial level of the culture of self-presentation of 1-2-year students was revealed, which makes it possible to determine the problems and main directions of psychological and pedagogical work on the formation of a culture of self-presentation of students at the next stage of professional training. In general, the results of the ascertaining stage of the experiment demonstrated that there are problems and gaps in all indicators of the culture of self-presentation: students did not pay enough attention to the knowledge on the basis of which the process of self-presentation was built, a significant part of the students experienced difficulties in self-presentation. In the process of interaction and communication, students used a fairly wide range of tactics and strategies of behavior, this indicates that the behavior of students was of a varied nature of presenting themselves as subjects of self-presentation, but they did not have enough knowledge on the use of one or another tactics and strategy in the course of selfpresentation.

Students also tend to avoid situations in which their shortcomings can become a target for public comment, and to behave in a way that hides their own imperfections from others. Students were characterized by a desire for recognition, respect, approval from others, as a rule, the most significant persons, to whose opinion they listen to the most and whose opinion they are guided primarily in their judgments, actions and views. They also noted difficulties in self-presentation when speaking in front of an audience, in emotional self-regulation.

Based on the results obtained in the further organization of psychological and pedagogical work on managing the process of forming a culture of self-presentation among future teachers, we paid attention to the following aspects: knowledge on the basis of which the process of selfpresentation is built; self-acceptance of students; skills to overcome fear of the public and emotional self-regulation; increasing the importance of self-presentation in interaction with others; a sense of self-worth, self-worth and increased self-esteem as components of self-presentation; readiness for the manifestation of creativity in self-presentation through the characteristics of creativity (flexibility, originality and originality); skills to establish contacts with others; reflection as a way to obtain information about oneself as a subject of self-presentation; planning and building your selfpresentation, achieving tangible results in self-presentation; knowledge of resisting the influence of other people and developing their own individual style of self-presentation; the skills of selforganization, self-regulation, the correct distribution of forces and time in self-presentation; selfknowledge skills in self-presentation; analysis of the effectiveness of their own actions in selfpresentation; presentation of an adequate image of "I" in self-presentation.

The analysis of the results of the ascertaining stage made it possible to create, before the start of the forming experiment, two compared samples (control and experimental groups), which were balanced in all indicators relevant for the study, reflecting the severity of individual indicators of the culture of self-presentation of students. In terms of the number of respondents, the experimental (105 people) and control (111 people) groups did not differ significantly, which made it possible to 
carry out a comparative analysis of the results of the formative experiment in the experimental group and the results of traditional education in the control group. Also, the results of the ascertaining stage determined the need to develop and implement in the experimental group special conditions for organizing the process and managing the process of forming a culture of the influence of traditional and contemporary art in self-presentation among future teachers, taking into account the results obtained.

Both educational and extracurricular activities were systematically carried out in the course of further professional training. Within the framework of the classroom and extracurricular work on the curriculum, lectures, practical classes, the influence of traditional and modern art in the pedagogical support of students during their pedagogical practice were held. An important form of work was the independent activity of students, carried out according to the developed assignments with methodological guidance and advice from teachers.

Also, the work consisted in identifying the influence of traditional and contemporary art in pedagogical support of students within the framework of the Aru Art Center of the Abai Kazakh National Pedagogical University through group and individual forms (consultations, work in practice).

At the control stage of the experiment, we re-diagnosed the indicators of the culture of selfpresentation in the experimental and control groups of students enrolled in the third and fourth courses. The main task of this stage was to assess the effectiveness of our formative experiment. Let us present the sequential statistical comparisons of the experimental and control groups for all indicators for each of the four components of the culture of self-presentation: literacy (cognitive component), competence component, value-semantic component, reflexive-evaluative component. We used Student's t-test for independent samples.

Table 1 presents the results of a comparative analysis of the literacy levels of the influence of traditional and contemporary art in pedagogical support in self-presentation of students of the experimental and control groups. Recall that to determine the cognitive component of the culture of self-presentation among students, the criterion-oriented test "Literacy in self-presentation" was used.

Table 1: Characteristics of literacy in the culture of self-presentation in EG and KGat the control stage of the experiment

\begin{tabular}{lrrrrc}
\hline Index & МЭГ & МКГ & t-value & df & $p$ \\
\hline Literacy & $\mathbf{1 5 , 3 7 1}$ & $\mathbf{9 , 4 0 5}$ & 13,739 & 214 & 0,000001
\end{tabular}

Note:

Note: МЭг - the average value of the indicator in the experimental group, Мкг the average value of theindicator in the control group, $t$-value -Student statistics, $p$ -the level of significance.

The results presented in Table 1 indicate that after the implementation of the influence of traditional and contemporary art in pedagogical support in a formative experiment, the literacy level 
of students in the experimental group turned out to be higher than in the control group ( $p$ $<0.000001)$.

Table 2 presents the results of a comparative analysis of indicators of the severity of the competence component of self-presentation of students in the experimental and control groups. To identify the competence component of the culture of influence of traditional and contemporary art of self-presentation, students used the following methods: Snyder's (1979) self-monitoring scale and others.

Table 2: Indicators of the competence component of the culture of the influence of traditional and modern art of self-presentation in the experimental and control groups at the control stage of the experiment

\begin{tabular}{lccccc}
\hline \multicolumn{1}{c}{ Index } & МЭГ & МКГ & t-value & $\mathrm{df}$ & $\mathrm{p}$ \\
\hline Self-monitoring indicator & $\mathbf{1 0 , 0 1}$ & 9,27 & 1,623 & 21 & 0,106 \\
Justification with denial of responsibility & $\mathbf{9}$ & 9 & & 4 & 0,734 \\
& 3,675 & 3,72 & $-0,339$ & 21 & 0,734 \\
Justification with Acceptance of & $\mathbf{4 , 1 4 7}$ & 3,44 & 5,087 & 21 & 0,00000 \\
Responsibility & & 1 & & 4 & 1 \\
Renunciation & 3,524 & 3,49 & 0,508 & 21 & 0,611 \\
An obstacle to yourself & 3,431 & 3,32 & 1,515 & 21 & 0,131 \\
Apology & 4,160 & 4,08 & 0,383 & 21 & 0,701 \\
Desire (effort) to please & & 7 & & 4 & \\
Intimidation & 4,343 & 4,09 & 1,355 & 21 & 0,176 \\
Request (supplication) & 3,075 & 3,05 & 0,236 & 21 & 0,812 \\
Ascribing achievements to yourself & 3,555 & 3,67 & $-1,253$ & 21 & 0,211 \\
Exaggerating your accomplishments & 3,036 & 3,15 & $-1,088$ & 21 & 0,277 \\
Negative assessment of others & 3,309 & 3,27 & 0,431 & 21 & 0,666 \\
Example carrier & 3,154 & 3,12 & 0,417 & 21 & 0,676 \\
& & 1 & & 4 & 0,439 \\
\hline
\end{tabular}

Note:

МЭГ -the average value of the indicator in the experimental group, Мкг -the average value of the indicator in thecontrol group, $t$-value - Student statistics, $p$ - the level of significance.

The results presented in table 2 indicate that after the formative experiment in general, the indicators in the experimental group are higher than in the control group. The indicator "Justification with the acceptance of responsibility" in the experimental group turned out to be statistically more pronounced than the analogous indicator in the control group $(p \leq 0.000001)$. Along with this, at the 
level of the statistical trend $(p<0.10)$, it was found that the level of self-monitoring in the experimental group also became higher than in the control group.

Table 3 presents the results of a comparative analysis of the indicators of the expression of the value-semantic component of the self-presentation of students of the experimental and control groups. To diagnose the value-semantic component of the culture of students' self-presentation, the following were used: questionnaire of terminal values, self-attitude research methodology (partially).

Table 3: Indicators of the value-semantic component of the culture of selfpresentationin the experimental and control groups at the control stage of the experiment

\begin{tabular}{llllll}
\hline \multicolumn{1}{c}{ Index } & МЭГ & МКГ & t-value & df & $\mathrm{p}$ \\
\hline Own prestige & $\mathbf{5 , 7 1 1}$ & 4,257 & 3,17 & 214 & 0,001 \\
High financial position & 4,114 & $\mathbf{6 , 7 7 4}$ & $-8,30$ & 214 & 0,0001 \\
Creativity & 5,847 & 6,018 & $-0,85$ & 214 & 0,45 \\
Active social contacts & $\mathbf{6 , 3 3 3}$ & 3,780 & 7,99 & 214 & 0,0001 \\
Developing yourself & $\mathbf{7 , 3 1 5}$ & 6,309 & 2,31 & 214 & 0,001 \\
Progress & $\mathbf{7 , 4 1 4}$ & 6,180 & 2,54 & 214 & 0,001 \\
Spiritual satisfaction & 4,723 & $\mathbf{6 , 4 1 4}$ & $-6,27$ & 214 & 0,0001 \\
Preserving your own individuality & 6,504 & $\mathbf{6 , 5 6 7}$ & $-0,32$ & 214 & 0,74 \\
Self-worth & 6,209 & 6,081 & 0,37 & 214 & 0,711 \\
Self-acceptance & $\mathbf{7 , 0 0 0}$ & 6,054 & $\mathbf{2 , 6 0}$ & 214 & 0,009 \\
\hline
\end{tabular}

Note: МЭГ - the average value of the indicator in the experimental group, Мкг - the average value of the indicatorin the control group, $t$-value - Student statistics, $p$ - the level of significance.

The results of statistical analysis presented in Table 3 indicate that at the control stage of the experiment, statistically significant differences were revealed between the experimental and control groups in a number of indicators of the severity of the value-semantic component of the culture of students' self-presentation. Thus, for the students who made up the experimental group, such values as their own prestige ( $\leq \leq 0.001)$, active social contacts ( $p \leq 0.00001)$, selfdevelopment $(p \leq 0.001)$ and achievements $(p \leq 0.001)$ became statistically more significant, and for the control group students - high financial status $(p \leq 0.0001)$ and spiritual satisfaction $(p \leq$ 0.0001).

Statistical analysis also indicates that at the control stage of the experiment, there are significant differences in self-attitude indicators between the experimental and control groups. In particular, it was found that in the experimental group, in comparison with the control group, such an indicator as self-acceptance is statistically higher $(p \leq 0.009)$.

Table 4 presents the results of a comparative analysis of the severity of the reflexiveevaluative component of the self-presentation of students in the experimental and control groups. To diagnose the reflexive-evaluative component of the culture of self-presentation of students, the following methods were used: the scale of perfectionist self-presentation, the 
Akmara, S., Orynbekovna, N.Z., Kuralay, B., Dzhaybulovna, J. Z., Erkinkyzy, R. S. \& Bektemirovna, K. (.2021). The Role of the Possibilities of the Influence of Traditional and Modern Art on the Self-presentation of Future Teachers. Cypriot Journal of Educational Science. 16(5), 27132725. https://doi.org/10.18844/cjes.v16i5.6361

method of determining the level of formation of pedagogical reflection, the method of selfattitude research (partially).

Table 4: Indicators of the expression of the reflexive-evaluative component of the culture of the influence of traditional and modern art of self-presentation in the experimental and control groups at the control stage of the experiment

\begin{tabular}{llllll}
\hline \multicolumn{1}{c}{ Index } & MЭГ & MКГ & t-value & df & \multicolumn{1}{c}{$p$} \\
\hline Demonstration of perfection & 36,019 & 36,675 & $-0,507$ & 214 & 0,612 \\
Behavioral non-manifestation of imperfection & 48,304 & $\mathbf{5 0 , 5 2 2}$ & $-1,835$ & 214 & 0,067 \\
Verbal non-manifestation of imperfection & 27,514 & $\mathbf{2 9 , 0 5 4}$ & $-1,478$ & 214 & 0,140 \\
Pedagogical reflection & $\mathbf{1 6 , 9 4 2}$ & 13,027 & 6,551 & 214 & 0,000001 \\
Isolation & 5,428 & $\mathbf{6 , 3 9 6}$ & $-2,701$ & 214 & 0,007 \\
Self-confidence & $\mathbf{7 , 2 6 6}$ & 4,936 & $\mathbf{7 , 4 9 7}$ & 214 & 0,000001 \\
Self-guidance & $\mathbf{7 , 7 3 3}$ & 6,117 & 5,152 & 214 & 0,000001 \\
Reflected self-attitude & $\mathbf{6 , 4 0 0}$ & 5,666 & 2,789 & 214 & 0,005 \\
Self-attachment & 4,542 & 4,639 & $-0,365$ & 214 & 0,715 \\
Internal conflict & 4,295 & $\mathbf{5 , 0 9 0}$ & $-3,411$ & 214 & 0,0007 \\
Self-accusation & 4,457 & $\mathbf{4 , 8 4 6}$ & $-1,706$ & 214 & 0,089 \\
\hline
\end{tabular}

Note: МЭг - the average value of the indicator in the experimental group, Мкг - the average value ofthe indicator in the control group, t-value - Student statistics, $\mathrm{p}$ - the level of significance.

The results presented in Table 4 indicate that at the final stage of the study in the experimental group, in comparison with the control group, such indicators of the reflexive-evaluative component of the culture of self-presentation as pedagogical reflection ( $p \leq 0.000001$ ), selfconfidence ( $p \leq 0.000001)$, self-guidance ( $p \leq 0.000001)$, reflected self-attitude $(p \leq 0.005)$ were statistically more pronounced. In the control group, the levels of behavioral rejection of imperfection $(p \leq 0.067)$, isolation $(p \leq 0.007)$, internal conflict $(p \leq 0.0007)$ and self-blame $(p \leq 0.089)$ were more pronounced.

\section{Discussion}

The analysis of the data obtained allows us to make a general conclusion that the formative experiment conducted by us led to significant changes in the parameters of the culture of selfpresentation of students of the experimental group in cognitive, competence, value-semantic and reflexive-evaluative components (Agranovich et al., 2019; Bagila et al., 2019; Yesnazar et al., 2020).

In the experimental group, the positive dynamics is more pronounced at the level of literacy in self-presentation, the level of self-monitoring in self-presentation and the level of formation of pedagogical reflection, data on value orientations and characteristics of self-attitude. The results obtained in the experimental group indicate a significant positive dynamic of the culture of selfpresentation of future teachers in its main components (Zhumabayeva et al., 2019;2020; Amirova et al., 2020).

We believe that the changes in the experimental group occurred during the implementation of the complex of the influence of traditional and modern art in pedagogical support of psychological and pedagogical conditions for the formation of a culture of self-presentation, which included a set of forms, methods and techniques of the organization of psychological and pedagogical activities 
Akmara, S., Orynbekovna, N.Z., Kuralay, B., Dzhaybulovna, J. Z., Erkinkyzy, R. S. \& Bektemirovna, K. (.2021). The Role of the Possibilities of the Influence of Traditional and Modern Art on the Self-presentation of Future Teachers. Cypriot Journal of Educational Science. 16(5), 27132725. https://doi.org/10.18844/cjes.v16i5.6361

aimed at the formation of indicators of the culture of self-presentation carried out through the educational and extracurricular activities of students (Karasheva et al., 2021; Spiridonova, 2017). Such work is not carried out enough in the traditional process of professional training of students, which obviously affects the image and status of the teacher in the future.

In the control group, where classes were conducted in accordance with the traditional curriculum, the positive dynamics is poorly expressed. Minor changes in the level of literacy in selfpresentation, the level of self-monitoring of self-presentation, the level of formation of pedagogical reflection, value orientations and values on the scales of self-attitude were revealed.

Thus, the formation of a culture of the influence of traditional and modern art in selfpresentation among future teachers at the stage of professional training at the university was facilitated by the implementation of a specially organized complex of the influence of traditional and modern art in pedagogical conditions (Spiridonova, 2017).

\section{Conclusion}

The study shows the significance and insufficient elaboration of the problem of the formation of the culture of the influence of traditional and modern art in self-presentation among future teachers as one of the factors determining the worthy position of a teacher in society and education. The theoretical analysis of psychological and pedagogical literature carried out by us allows us to systematize ideas about the phenomenon of the culture of self-presentation of a teacher as an integral part of the professional psychological culture of a teacher. The presented definition of the culture of self-presentation of a teacher and its components, which were formulated and highlighted by us, allow us to consider the culture of self-presentation of a teacher as an integral part of pedagogical communication, pedagogical skills, professional activity of a teacher.

A study in the logic of a formative psychological and pedagogical experiment in order to determine the effectiveness of the implementation of the developed complex of psychological and pedagogical conditions as a way of organizing and managing the process of forming a culture of selfpresentation among future teachers has shown that increasing the level of self-presentation culture is possible. We believe that a significant contribution to the formation of the possibilities of the influence of traditional and modern art of the culture of self-presentation of students was made by their pedagogical support within the framework of the ARU Art Center of the Abai Kaakh National Pedagogical University, in particular, the training "The possibilities of the influence of traditional and modern art on self-presentation among future teachers."

Various forms of work in academic and extracurricular activities for two years have led to significant positive changes. At the control stage of the experiment, positive dynamics was noted in the experimental group in terms of cognitive, competence, reflexive-evaluative and value-semantic components of the culture of self-presentation. The most significant positive changes were reflected in the following indicators of the culture of self-presentation of future teachers: the level of literacy of students in self-presentation, the level of self-monitoring in students' self-presentation, the level of formation of pedagogical reflection of students, characteristics of value orientations (own prestige, active social contacts, self-development, achievements), characteristics of self-attitude (self-confidence, self-guidance, reflected self-attitude, self-worth, self-acceptance). The significance of the changes was confirmed by the student's t-test. 
Akmara, S., Orynbekovna, N.Z., Kuralay, B., Dzhaybulovna, J. Z., Erkinkyzy, R. S. \& Bektemirovna, K. (.2021). The Role of the Possibilities of the Influence of Traditional and Modern Art on the Self-presentation of Future Teachers. Cypriot Journal of Educational Science. 16(5), 27132725. https://doi.org/10.18844/cjes.v16i5.6361

The implementation of specially organized psychological and pedagogical conditions for the formation of a culture of self-presentation of future teachers in a sufficiently complete volume is more effective than individual unsystematic traditional forms of organizing the educational process without reinforcement through psychological support within the framework of the psychological service of the university. The obtained data can be used in the activities of universities to improve the culture of self-presentation in professional and interpersonal interaction among representatives of related professions in the process of their professional training.

\section{Acknowledgement}

The article is published on the topic of the scientific project AP08053283 - "The evolution of eco-design in traditional and modern national art in art education", approved as part of a grant from the Committee of Science, the Ministry of Education and Science of the Republic of Kazakhstan to finance fundamental and applied scientific projects.

\section{References}

Agranovich, Y., Amirova, A., Ageyeva, L., Lebedeva, L., Aldibekova, S., \& Uaidullakyzy, E. (2019). The Formation of Self-Organizational Skills of Student's Academic Activity on the Basis of 'Time Management'Technology. International Journal of Emerging Technologies in Learning (iJET), 14(22), 95110. https://online-journals.org/index.php/i-jet/issue

Amirova, A., Iskakovna, J.M., Zakaryanovna, T.G., Nurmakhanovna, Z.T., Elmira U. (2020). Creative and research competence as a factor of professional training of future teachers: Perspective of learning technology. World Journal on Educational Technology: Current Issues, 2020, 12(4), стр. 278-289 https://unpub.eu/ojs/index.php/cjes/issue

Anokhina N. F. (2013). Teacher self-presentation in the internet space. Educational Technology, 2013, no.4, pp. 133-140. (In Russian) URL: https://www.elibrary.ru/item.asp?id=18904852

Bagila, S., Kok, A., Zhumabaeva, A., Suleimenova, Z., Riskulbekova, A., \& Uaidullakyzy, E. (2019). Teaching Primary School Pupils Through Audio-Visual Means. International Journal of Emerging Technologies in Learning (iJET), 14(22), 122-140. https://online-journals.org/index.php/i-jet/issue

Bulavkina, E. B., \& Mayer A. A. (2018). Creative self-presentation of the teacher of preschool education in the conditions of competition of professional skill. Vestnik of State University of Humanities and Technology, 2018, no. 4, pp. 16-18. (In Russian) URL: https://www.elibrary.ru/item.asp?id=36813959

Chekalina, A. A. (2012). About features of self-presentation of women-teachers. Theory and Practice of Social Development, 2012, no. 3, pp. 85-88. (In Russian) URL: https://www.elibrary.ru/item.asp?id=17678028

Chen, J. (2019). efficacious and positive teachers achieve more: Examining the relationship between teacher efficacy, emotions, and their practicum performance. The Asia-Pacific Education Researcher, 2019, vol. 28 (4), pp. 327-337. DOI: https://doi.org/10.1007/s40299-018-0427-9

Forster-Heinzer, S., Nagel, A., \& Biedermann, H. (2019). The power of appearance: Students' impression management within class. Pedagogy and Pedagogical Challenges, 2019. DOI: http://dx.doi.org/10.5772/intechopen.88850

Frenzel, A. C., Taxer, J. L., Schwab, C., \& Kuhbandner, C. (2019). Independent and joint effects of teacher enthusiasm and motivation on student motivation and experiences: A field experiment. Motivationand 
Akmara, S., Orynbekovna, N.Z., Kuralay, B., Dzhaybulovna, J. Z., Erkinkyzy, R. S. \& Bektemirovna, K. (.2021). The Role of the Possibilities of the Influence of Traditional and Modern Art on the Self-presentation of Future Teachers. Cypriot Journal of Educational Science. 16(5), 27132725. https://doi.org/10.18844/cjes.v16i5.6361

Emotion, 2019, vol. 43 (2), pp. 255-265. DOI: https://doi.org/10.1007/s11031-018-9738-7

Gluhih, S. I. (2012). The image of the modern teacher as a condition of formation of professional competence. Education, 2012, no. 2, pp. 112-116. (In Russian) URL: https://www.elibrary.ru/item.asp?id=17637710

Hayik, R., (2019). Weiner-Levy N. Prospective Arab teachers' emotions as mirrors to their identities and culture. Teaching and Teacher Education, 2019, vol. 85, pp. 36-44. DOI: https://doi.org/10.1016/j.tate.2019.05.006

Karasheva, Z., Amirova, A., Ageyeva, L., Jazdykbayeva, M., Uaidullakyzy, E. (2021). Preparation of future specialists for the formation of educational communication skills for elementary school children. World Journal on Educational Technology: Current Issuesthis link is disabled, 2021, 13(3), cтp. 467-484 https://www.un-pub.eu/ojs/index.php/wjet/issue

Kolmogorova L. S., \& Spiridonova G. G. (2015). Characteristics of self-introduction in the context of internal and external components of personal culture. The World of Science, Culture and Education, 2015, no. 4, pp. 180-182. (In Russian) URL: https://www.elibrary.ru/item.asp?id=24107674

Kolmogorova, L. S. (2013). Formation of psychological culture of pupils in the conditions of education: monograph. Barnaul: AltGPU, 2013, p. 237. (In Russian) URL: https://elibrary.ru/item.asp?id=25427114

Kolmogorova, L. S., \& Spiridonova G. G. (2017). Culture self-representation as a component of pedagogical communication. Bulletin of the Kazakh Humanitarian and Juridical Innovation University, 2017, no. 1, pp. 133-138. (In Russian) URL: https://www.elibrary.ru/item.asp?id=32470939

Kolyuzhny, A. A. (2004). Psycology teacher image formation. Moscow: VLADOS, 2004, p. 222. (In Russian) URL: https://elibrary.ru/item.asp?id=20240083

Nebessayeva, Zh. O., Duisekhanov, T., Jartybayeva, Z. D., Kunzhigitova, G.B., Rsmakhanbetova, S. E., \& Kamalov, Y. (2021) Pedagogical Education with Updated Content Based on an Integrative Approach// Linguistica Antverpiensia, Issue-1, 31 March, 2021, https://www.hivt.be/linguistica/article/view/612/368

Ödalen J., Brommesson D., Erlingsson G. O., Schaffer J. K., Fogelgren M. (2019). Teaching university teachers to become better teachers: the effects of pedagogical training courses at six Swedish universities. Higher Education Research \& Development, 2019, vol. 38 (2), pp. 339-353. DOI: https://doi.org/10.1080/07294360.2018.1512955

Popova, O. I. (2008). Teacher of higher education institution: a modern view on profession. Experience of sociological research. Teacher Education in Russia, 2012, no. 6, pp. 112-119. (In Russian) URL: https://www.elibrary.ru/item.asp?id=18756889

Saidah, B., Louvet, E., \& Pansu, P. (2019). Are students who make an effort perceived as successful or just liked by their teachers? Social Psychology of Education, 2019, vol. 22 (2), pp. 405-419. DOI: https://doi.org/10.1007/s11218-019-09481-x

Schmidt, J., Klusmann U., Lüdtke O., Möller J. \& Kunter M. (2017). What makes good and bad days for beginning teachers? A diary study on daily uplifts and hassles. Contemporary Educational Psychology, 2017, vol. 48, pp. 85-97. DOI: https://doi.org/10.1016/j.cedpsych.2016.09.004

Semenova, L. E. (2008). Self-presentation in male teachers working in secondary school in the context of their professional activity. Psychological Science and Education, 2008, no. 1, pp. 82-89. (In Russian)URL: https://www.elibrary.ru/item.asp?id=11750597

Snyder, M. (1979). Self-monitoring processes. In Advances in experimental social psychology (Vol. 12, pp. 85128). Academic Press. https://www.sciencedirect.com/science/article/pii/S0065260108602609

Spiridonova, G. G. (2015). Self-presentation culture in the professional activity of a teacher. Education andSociety. Psychological Sciences, 2015, no. 5, pp. 98-102. (In Russian) URL: 
Akmara, S., Orynbekovna, N.Z., Kuralay, B., Dzhaybulovna, J. Z., Erkinkyzy, R. S. \& Bektemirovna, K. (.2021). The Role of the Possibilities of the Influence of Traditional and Modern Art on the Self-presentation of Future Teachers. Cypriot Journal of Educational Science. 16(5), 27132725. https://doi.org/10.18844/cjes.v16i5.6361

https://elibrary.ru/item.asp?id=25393910

Spiridonova, G. G. (2017). The structure and content of the teacher's self-presentation culture as acharacteristic of his psychological culture. Education and Society. Psychological Sciences, 2017 no. 2-3, pp. 77-80. (In Russian) URL: https://elibrary.ru/item.asp?id=30773413

Tsybulsky, D., Muchnik-Rozanov, Y. (2019). The development of student-teachers' professional identity while team-teaching science classes using a project-based learning approach: A multi-level analysis. Teaching and Teacher Education, 2019, vol. 79, pp. 48-59. DOI: https://doi.org/10.1016/j.tate.2018.12.006

Yesnazar, A., Japbarov, A., Zhorabekova, A., Nuralieva, A., Elmira U. (2020). Determination of primary school children's speech skills in interdisciplinary communication in learning environments. World Journal on Educational Technology: Current Issues, 2020, 12(4), стр. 373-388 https://unpub.eu/ojs/index.php/cjes/issue

Zhumabayeva, E., Kdyrbaeva, A.A., Nurzhanova S.A., Stambekova, S., \& Uaidullakyzy, E. (2020). Implementing Polylingual Space into the Process of Training Future Primary School Teachers. Tejuelo 31, 307-324. Doi: https://doi.org/10.17398/1988-8430.31.307

Zhumabayeva, Z., Uaisova, G., Zhumabayeva, A., Uaidullakyzy, E., Karimova, R., \& Hamza, G. (2019). Issues of Kazakh language teaching in elementary classes in terms of the meta-subject approach. , 14(1), 158-170. https://un-pub.eu/ojs/index.php/cjes/issue 